\title{
Review \\ COVID-19 Vaccines in Patients with Maintenance Hemodialysis
}

\author{
Cheng-Chieh Yen ${ }^{1,2} \mathbb{D}$, Shang-Yi Lin ${ }^{3,4}$, Szu-Chia Chen ${ }^{4,5,6} \mathbb{D}$, Yi-Wen Chiu ${ }^{4,5} \mathbb{D}$, Jer-Ming Chang \\ and Shang-Jyh Hwang 4,5,7,*
}

1 Division of Nephrology, Department of Internal Medicine, Ditmanson Medical Foundation, Chia-Yi Christian Hospital, Chia-Yi City 60002, Taiwan; u9001017@gmail.com

2 Division of Nephrology, Chiayi Hospital, Ministry of Health and Welfare, Chia-Yi City 60096, Taiwan

3 Division of Infectious Diseases, Department of Internal Medicine, Kaohsiung Medical University Hospital, Kaohsiung 80756, Taiwan; amoe616@gmail.com

4 Faculty of Medicine, College of Medicine, Kaohsiung Medical University, Kaohsiung 80756, Taiwan; scarchenone@yahoo.com.tw (S.-C.C.); chiuyiwen@kmu.edu.tw (Y.-W.C.); jemich@kmu.edu.tw (J.-M.C.)

5 Division of Nephrology, Department of Internal Medicine, Kaohsiung Medical University Hospital, Kaohsiung Medical University, Kaohsiung 80756, Taiwan

6 Department of Internal Medicine, Kaohsiung Municipal Siaogang Hospital, Kaohsiung Medical University, Kaohsiung 81267, Taiwan

7 Institute of Population Health Sciences, National Health Research Institutes, Miaoli 35053, Taiwan

* Correspondence: sjhwang@kmu.edu.tw; Tel.: +886-7-3121101 (ext. 7900) or +886-7-3121101 (ext. 7901) or +886-7-3121101 (ext. 5106)

check for updates

Citation: Yen, C.-C.; Lin, S.-Y.; Chen, S.-C.; Chiu, Y.-W.; Chang, J.-M.; Hwang, S.-J. COVID-19 Vaccines in Patients with Maintenance Hemodialysis. J. Pers. Med. 2021, 11, 789. https://doi.org/10.3390// jpm11080789

Academic Editor: Roger E. Thomas

Received: 5 July 2021

Accepted: 11 August 2021

Published: 12 August 2021

Publisher's Note: MDPI stays neutral with regard to jurisdictional claims in published maps and institutional affiliations.

Copyright: (c) 2021 by the authors. Licensee MDPI, Basel, Switzerland. This article is an open access article distributed under the terms and conditions of the Creative Commons Attribution (CC BY) license (https:/ / creativecommons.org/licenses/by/ $4.0 /)$.

\begin{abstract}
The COVID-19 pandemic has infected more than 180 million people and caused more than 3.95 million deaths worldwide. In addition to personal hygiene, augmented cleaning, social distancing, and isolation, vaccine development and immunization are essential for this highly contagious disease. Patients with maintenance hemodialysis (MHD) have a greater risk of COVID-19 infection owing to their comorbidities, defective immunity, and repeated crowded in-center dialysis settings. However, many patients hesitate to get vaccinated because of their misunderstandings. The Efficacy of COVID-19 vaccination has been intensively discussed in the general population, whereas the data concerning the effectiveness of vaccination in MHD patients are relatively scanty. Nevertheless, those limited publications can provide some valuable information. Overall, lower and more delayed antibody responses following COVID-19 vaccination were observed in patients with MHD than in healthy controls in the settings of different populations, vaccines and dosage, definitions of the immune response, and antibody detection timepoints. Younger age, previous COVID-19 infection, and higher serum albumin level were positively associated with antibody formation, whereas older age and receiving immunosuppressive therapy were unfavorable factors. However, it remains uncertain between the elicited antibodies following vaccination and the genuine protection against COVID-19 infection. Patients with MHD should make their COVID-19 vaccination a priority in addition to other protective measures. More studies focusing on different vaccines, non-humoral immune responses, and risk-benefit analyses are warranted.
\end{abstract}

Keywords: anti-SARS-CoV-2 antibody; COVID-19 infection; COVID-19 vaccines; effectiveness; hemodialysis

\section{The COVID-19 Pandemic}

In December 2019, a novel coronavirus was first detected in Wuhan, China. People who were infected by the virus manifested mostly as fever and pulmonary symptoms including dyspnea, productive cough, respiratory failure, and acute respiratory distress syndrome. Extrapulmonary involvements of the cardiovascular, gastrointestinal and, renal systems were also reported [1]. Owing to its rapid transmission, high contagiousness, and mortality, the World Health Organization (WHO) declared the outbreak a public 
health emergency of international concern on 30 January 2020. The virus was officially named severe acute respiratory syndrome coronavirus 2 (SARS-CoV-2) and the disease it caused was termed coronavirus disease 2019 (COVID-19) by the WHO on 11 February 2020. COVID-19 was then declared a pandemic on 11 March 2020. To date, more than 180 million people have been infected and 3.95 million people have died of COVID-19 [2].

Various treatment modalities for COVID-19 have been widely studied during the pandemic. Remdesivir can lessen respiratory symptoms and shorten the clinical course of hospitalization adult COVID-19 patients [3] and dexamethasone can improve the outcomes of hospitalized COVID-19 patients with oxygen dependence including mechanical ventilation [4]. However, the effectiveness of other medicines in the antiviral, anti-inflammatory, and immune-based fields remains uncertain. Since there are few effective treatments to control COVID-19, fundamental methods of stopping the spread of contagious diseases, including promoting personal hygiene and cleaning, enhancing decontamination, maintaining social distance, quarantine, isolation, and vaccine development and immunization are crucial.

\section{COVID-19 in Hemodialysis Patients}

End-stage renal disease (ESRD) is a condition defined as a renal function that cannot meet the homeostasis of waste, fluid, and electrolytes. According to the send edition of the Global Kidney Health Atlas published by the International Society of Nephrology in 2019, more than 2 million ESRD patients require dialysis or transplantation to stay alive, and hemodialysis is the most commonly used modality to treat ESRD [5]. Owing to their uremia and high burden of comorbidities including hypertension, diabetes, cardiovascular disease, and malignancy, patients with maintenance hemodialysis (MHD) have higher mortality than the general population. In addition, infectious diseases and sepsis are the major causes of hospitalization and mortality in this vulnerable population due to defects in innate and adaptive immunity [6,7].

Patients with MHD mostly receive their dialysis in the form of in-center hemodialysis and have to spend at least 10-15 h inside dialysis institutes with unavoidable proximity to other patients and medical personnel. Such a characteristic could increase the risk of accelerating the transmission of infectious diseases. Data from a national dialysis provider in the United States revealed that a crowded setting resulted in a 17-fold higher risk of SARS-CoV-2 infection [8]. The reported prevalence of COVID-19 among patients with MHD ranges from $5.3 \%$ to $36.2 \%$, which is $5-16$ times higher than the general population, and a mortality rate exceeding $20 \%$ [8-11].

\section{Vaccination in Hemodialysis Patients}

In spite of the defensive methods for COVID-19, patients with MHD remain at a higher risk of infection owing to their comorbidities, frequent invasive procedures, and crowded dialysis settings. Vaccination has been demonstrated to reduce the infection rate of some diseases including influenza, hepatitis B, and pneumococcal pneumonia in this cohort. However, many MHD patients hesitate to vaccinate owing to incomplete understanding and lack of trustworthy information. It results in a low rate of vaccination of the abovementioned vaccines [12] and is similar in the case of the COVID-19 vaccines. Given that there are few effective medicines to treat COVID-19 at present and the high risk and possible mortality of the disease in MHD patients, vaccination is essential in addition to heightened sanitation, maintaining social distance, and cleaning. Major nephrology societies including the Internal Society of Nephrology, the American Society of Nephrology, and European Dialysis and Transplant Association-European Renal Association urge making COVID-19 vaccination a priority in this vulnerable population [13-15]. However, even in the United States, many MHD patients hesitate to receive a vaccination in consideration of the adverse effects [16]. 


\section{COVID-19 Vaccines}

Nearly 300 COVID-19 vaccine candidates have been developed to date and more than 100 are under clinical trials [17]. The brief summary below focuses on the vaccines which have received multinational emergency use authorization (EUA) and the preliminary results of their Phase 3 trials are listed in Table 1.

Table 1. Progress of COVID-19 vaccines acquiring multinational emergency use authorizations.

\begin{tabular}{|c|c|c|c|c|c|c|}
\hline Vaccine & Brand Name & Manufacturer & Type & $\begin{array}{l}\text { WHO } \\
\text { EUA }\end{array}$ & EUA Countries & $\begin{array}{l}\text { Preliminary or Final Results } \\
\text { of Phase } 3 \text { Trial(s) }\end{array}$ \\
\hline CoronaVac & CoronaVac & $\begin{array}{l}\text { Sinovac } \\
\text { Biotech }\end{array}$ & $\begin{array}{l}\text { Inactivated } \\
\text { whole virus }\end{array}$ & Yes & 26 & $\begin{array}{l}434 \text { participants enrolled; a } \\
\text { SCR in neutralizing antibodies } \\
\text { of } 90 \% \text { to } 95.6 \% \text { and an } \\
\text { IFN- } \gamma \text {-based T cell response } \\
\text { increase of } 14.04 \text { to } 33.81 \text { times } \\
\text { on day } 28 \text { [18] }\end{array}$ \\
\hline BBIBP-CorV & & Sinopharm & $\begin{array}{l}\text { Inactivated } \\
\text { whole virus }\end{array}$ & Yes & 45 & $\begin{array}{l}40382 \text { participants enrolled; } \\
\text { efficacy of } 72.8 \% \text { to } 78.1 \% \text { in } \\
\text { preventing COVID-19 [19] }\end{array}$ \\
\hline BBV152 & Covaxin & $\begin{array}{l}\text { Bharat } \\
\text { Biotech }\end{array}$ & $\begin{array}{l}\text { Inactivated } \\
\text { whole virus }\end{array}$ & No & 9 & $\begin{array}{l}25800 \text { participants enrolled; } \\
\text { efficacy of } 80.6 \% \text { in preventing } \\
\text { asymptomatic COVID-19 }\end{array}$ \\
\hline AZD1222 & Vaxzevria & $\begin{array}{l}\text { Oxford } \\
\text { University } \\
\text { and As- } \\
\text { traZeneca }\end{array}$ & Viral vector & Yes & 102 & $\begin{array}{l}32449 \text { participants enrolled; } \\
\text { efficacy of } 79 \% \text { and } 100 \% \text { in } \\
\text { preventing symptomatic } \\
\text { COVID-19 and severe disease } \\
\text { and hospitalization, } \\
\text { respectively }\end{array}$ \\
\hline Gam-COVID-Vac & Sputnik V & $\begin{array}{l}\text { Gamaleya } \\
\text { National } \\
\text { Research } \\
\text { left }\end{array}$ & Viral vector & No & 68 & $\begin{array}{l}21977 \text { participants enrolled; } \\
\text { efficacy of } 91.6 \% \text { and } 100 \% \text { in } \\
\text { preventing COVID-19 and } \\
\text { moderate or severe COVID-19, } \\
\text { respectively; a SCR of } 98.25 \% \\
\text { and a GMT of } 8996 \text { in } \\
\text { RBD-specific IgG on day } 42 \text {; a } \\
\text { higher levels of IFN- } \gamma \\
\text { secretion on day } 28 \text { [20] }\end{array}$ \\
\hline Ad26.COV2.S & & $\begin{array}{l}\text { Johnson \& } \\
\text { Johnson }\end{array}$ & Viral vector & Yes & 44 & $\begin{array}{l}44325 \text { participants enrolled; } \\
\text { efficacy of } 66.1 \% \text { and } 85.4 \% \text { in } \\
\text { preventing moderate to } \\
\text { severe-critical COVID-19 and } \\
\text { severe-critical COVID-19, } \\
\text { respectively [21] }\end{array}$ \\
\hline Ad5-nCoV & Convidecia & $\begin{array}{l}\text { CanSino } \\
\text { Biologics }\end{array}$ & Viral vector & No & 5 & $\begin{array}{l}40000 \text { participants planned; } \\
\text { efficacy of } 65.7 \% \text { and } 91 \% \text { in } \\
\text { preventing moderate } \\
\text { COVID-19 and severe } \\
\text { COVID-19, respectively }\end{array}$ \\
\hline BNT162b2 & Comirnaty & $\begin{array}{l}\text { Pfizer and } \\
\text { BioNTech }\end{array}$ & mRNA & Yes & 85 & $\begin{array}{l}43548 \text { participants enrolled; } \\
\text { efficacy of } 95 \% \text { in preventing } \\
\text { COVID-19 [22] }\end{array}$ \\
\hline mRNA-1273 & Spikevax & Moderna & mRNA & Yes & 49 & $\begin{array}{l}30420 \text { participants enrolled; } \\
\text { efficacy of } 94.1 \% \text { in preventing } \\
\text { COVID-19 [23] }\end{array}$ \\
\hline ZF2001 & Zifivax & $\begin{array}{l}\text { Anhui } \\
\text { Zhifei } \\
\text { Longcom }\end{array}$ & $\begin{array}{l}\text { Protein } \\
\text { subunit }\end{array}$ & No & 2 & 29000 participants enrolled \\
\hline EpiVacCorona & & $\begin{array}{l}\text { Vector State } \\
\text { Research } \\
\text { left }\end{array}$ & $\begin{array}{l}\text { Protein } \\
\text { subunit }\end{array}$ & No & 2 & 3000 participants planned \\
\hline
\end{tabular}




\subsection{Inactivated Whole Virus Vaccines}

An inactivated or killed whole virus vaccine comprises artificially cultured virus particles that do not have the ability to replicate and infect. The human immune system recognizes the entire virus particle as an immunogen following injection, which induces an adaptive immune response. There are three inactivated whole virus vaccines that have received multinational EUA for COVID-19 infection at present. CoronaVac has completed a Phase 2 trial of 950 adult participants and revealed a seroconversion rate (SCR) of $90.7 \%$ to $100 \%$ and neutralizing antibody geometric mean titers (GMTs) of 23.8 to 65.4 compared to placebo on Day 28 following vaccination [24,25]. BBIBP-CorV has completed a Phase 2 trial of 448 adult participants and revealed a SCR of $100 \%$ and GMTs of 14.7 to 282.7 in three vaccinated groups on Day 28 following vaccination [26]. BBV152 has completed a Phase 2 trial of 380 participants aged 12 to 65 years and revealed a SCR of $88 \%$ to $98.3 \%$ and GMTs of 100.9 to 197 in both groups receiving vaccination on Day 56 [27].

\subsection{Viral Vector Vaccines}

A viral vector, or deoxyribonucleic acid (DNA) vaccine, is a vaccine utilizing a nonpathogenic, usually replicative-deficient virus, to transport the gene of the immunogen into the human body. The modified virus will produce the immunogen to elicit an immune response following injection. With regards to COVID-19 viral vector vaccines, the ribonucleic acid (RNA) of spike protein, which is the pathogenic factor of SARS-CoV-2, is reverse transcribed to DNA and inserted into the genome of the chosen virus by genetic engineering. Nowadays, four viral vector vaccines have received multinational EUA for COVID-19 infection. AZD1222 was developed via modified chimpanzee adenovirus ChAdOx1. It has completed a Phase 2 trial of 23,848 adult participants and revealed an overall efficacy of $70.4 \%$ in participants receiving two doses of AZD1222 compared to placebo on Day 14 following vaccination [28]. Gam-COVID-Vac was developed via recombinant human adenovirus Type 26 and Type 5. It has completed a Phase 2 trial of 20 participants aged 18 to 60 years and revealed a SCR of $100 \%$ and GMTs of 45.95 and 49.25 in participants receiving vaccination on Day 42. In addition, significant cell-mediated responses were observed on Day 28 [29]. Ad26.COV2.S was developed via human adenovirus Serotype 26. It has completed a Phase 1-2a trial of 805 adult participants and revealed a SCR of $96 \%$ and GMTs of 288 to 488 in participants receiving the first dose of the vaccine on Day 57. A nearly three-fold increase in neutralizing antibody titers was observed following the second dose of the vaccine. In addition, cellular immunity was detected in $60 \%$ to $83 \%$ of the participants on Day 15 [30]. Ad5-nCoV, developed via recombinant human adenovirus Type 5, has completed a Phase 2 trial of 508 adult participants and revealed a SCR of $96 \%$ to $97 \%$ and GMTs of 18.3 to 19.5 on Day 28 in participants with a single injection [31].

\subsection{Messenger RNA Vaccines}

A messenger RNA (mRNA) vaccine is made by artificially synthesizing the mRNA of the immunogen to induce an immune response. Once the vaccine is injected, the immunogen is produced by interactions between its mRNA and ribosomes of the host cells [32]. With regards to COVID-19 mRNA vaccines, the mRNA of SARS-CoV-2 spike protein is manufactured and delivered in the form of lipid nanoparticles into the human body. Two mRNA vaccines of multinational EUA are available for COVID-19 infection now. BNT162b2 was developed using mRNA containing full-length spike protein. It has completed a Phase 2/3 trial of 43,448 participants aged over 16 years and revealed an efficacy of 95\% in preventing COVID-19 7 days after vaccination [22]. mRNA-1273 was also developed using full-length spike protein mRNA. It has completed a Phase 2 trial of 600 adult participants and revealed a SCR of $100 \%$ and GMTs of 1686 to 1909 in participants receiving vaccination on Day 43 [33]. 


\subsection{Protein Subunit Vaccines}

A protein subunit vaccine utilizes protein molecule(s) as an immunogen to elicit an immune response following injection [34]. COVID-19 protein subunit vaccines are manufactured with the fragment(s) of the spike protein. They are free of hereditary substances and are thus distinct from vaccines made of an inactivated whole virus, reverse transcribed DNA or mRNA of the spike protein, and will not revert to the virulence of SARSCoV-2. Two protein subunit vaccines of multinational EUA for COVID-19 infection are available currently. ZF2001 is a dimeric form of the SARS-CoV-2 receptor-binding domain (RBD). It has completed a Phase 2 trial of 900 participants aged 18 to 59 years and revealed a SCR of $93 \%$ to $97 \%$ and GMTs of 69.1 to 102.5 in participants who completed a threedose-schedule after 14 days [35]. EpiVacCorona is a combination product of SARS-CoV-2 nucleocapsid protein, three fragments of the spike protein, and a bacterial maltose-binding protein designed and manufactured. It has completed a Phase 2 trial of 86 participants aged 18 to 60 years and revealed a SCR of 100\% and GMT of 48.16 in participants 21 days following the second dose of the vaccine [36].

\section{Effectiveness of COVID-19 Vaccines in Hemodialysis Patients}

No patients with MHD have been recruited into efficacy trials of COVID-19 vaccines at present. In order to understand the effectiveness of COVID-19 vaccines in patients with MHD, we performed a literature search up to 03 July 2021 from the PubMed/MEDLINE electronic databases with the following search words: "SARS-CoV-2" or "COVID-19" and "vaccine" or "vaccination" and "hemodialysis". Our search criteria were restricted to the English language. All relevant original articles, case series, or case reports were screened in our analysis based on their topics, impacts, and data availability. In total, 23 suitable studies were pooled in the review and divided into the category of "vaccine effectiveness between patients with MHD and healthy controls" and "characteristics following vaccination in patients with MHD".

\subsection{Comparison of Vaccine Effectiveness between Patients with MHD and Healthy Controls}

Studies comparing the effectiveness following COVID-19 vaccination are summarized in Table 2. The results show that the antibody titers of patients with MHD were significantly lower than those of healthy controls, regardless of the antibody detecting methods used. It might partially result from the distinct age distribution of participants in both groups. Jahn et al. compared the titer of anti-spike protein glycoprotein IgG antibody two weeks after the second dose of BNT162b2 between 72 patients with MHD and 16 healthy healthcare workers and found that the seroresponses were significantly lower in MHD patients aged over 60 years [37]. Yanay et al. conducted a similar experiment of 127 MHD patients and 132 controls, and reported lower anti-spike antibody levels 21 to 35 days following two-dose BNT162b2 vaccinations in the dialysis group, particularly in those aged over 75 years [38]. Another experiment of 56 patients on MHD and 95 healthcare workers by Grupper et al. reported a significant inverse correlation between age and antibody levels in both groups 30 days following the second dose of BNT162b2 [39]. In addition, patients with MHD exhibited delayed humoral responses following COVID-19 vaccination. Goupil et al. reported that only $43 \%$ of 131 MHD patients had positive anti-RBD IgG levels, four weeks following a single dose of BNT162b2, compared to $95 \%$ of 20 controls [40]. Speer et al. also reported that $18 \%$ of 22 patients with dialysis had an early humoral response, compared to $93 \%$ of 46 controls, 17-22 days following the first dose of BNT162b2 [41]. Moreover, Simon et al. compared the adverse events of the participants following BNT162b2 vaccination. The local adverse effect such as pain following vaccination was reported in $10 \%$ to $20 \%$ of patients with MHD, whereas that was reported in $50 \%$ to $60 \%$ of healthy controls. The systemic adverse effect such as fatigue, headache or musculoskeletal pain was reported less than $10 \%$ of patients with MHD, whereas that was reported in $20 \%$ to $30 \%$ of healthy controls [42]. Danthu et al. analyzed the serial change of the anti-SARS-CoV-2 IgG antibodies among $78 \mathrm{MHD}$ patients and seven healthy controls following two doses of BNT162b2. 
Serum albumin level and dialysis adequacy were reported positively correlated with humoral response, whereas the previous non-responsiveness of hepatitis B vaccination was negatively correlated with humoral response [43]. Rincon-Arevalo et al. conducted an experiment utilizing flow cytometry to observe the distribution of $\mathrm{B}$ and plasma cells specific to SARS-CoV-2 spike protein RBD. The RBD-specific B cells were identified mostly among subsets of the pre-switch and naïve B cells in 40 MHD patients, whereas mostly among subsets of the plasmablast or post-switch memory B cell in 35 healthy controls [44]. Taken together, these studies displayed the poor immune responses of patients with MHD following COVID-19 vaccination.

Table 2. Comparison of effectiveness following COVID-19 vaccination between patients with MHD and healthy controls.

\begin{tabular}{|c|c|c|c|c|c|c|c|}
\hline Country & Vaccine & MHDs & Controls & MHDs Ab & Controls $\mathrm{Ab}$ & Other Significant Findings & Ref. \\
\hline Austria & BNT162b2 & 81 & 80 & $171 \mathrm{U} / \mathrm{mL}$ & $2500 \mathrm{U} / \mathrm{mL}$ & $\begin{array}{l}\text { MHDs exhibited lower local and } \\
\text { systemic AE compared to controls (local: } \\
\text { first dose: } p=0.006 \text {, second dose: } \\
p<0.0001 \text {; systemic: first } \\
\text { dose: } p=0.0005 \text {, second dose: } p<0.0001 \text { ) }\end{array}$ & [42] \\
\hline Canada & BNT162b2 & 154 & 40 & $9.5 \mathrm{RLU}^{\mathrm{a}}$ & $124.5 \mathrm{RLU}^{\mathrm{a}}$ & $\begin{array}{l}\text { Anti-RBD IgG level detection rate of 34\% } \\
\text { and } 53 \% \text { in older MHDs and younger } \\
\text { MHDs, } 19 \% \text { and } 48 \% \text { in MHDs with } \\
\text { immunosuppresants and MHDs without } \\
\text { immunosuppresants following } \\
\text { single-dose vaccination, respectively }\end{array}$ & [40] \\
\hline France & BNT162b2 & 78 & 7 & $114 \mathrm{AU} / \mathrm{mL}$ & $1082 \mathrm{AU} / \mathrm{mL}$ & $\begin{array}{l}\text { Anti-SARS-CoV-2 IgG of } 36,113.5 \text {, and } \\
209 \mathrm{AU} / \mathrm{ml} \text { in non-responders, } \\
\text { intermediate responders, and high } \\
\text { responders to HBV vaccine, respectively }\end{array}$ & [43] \\
\hline Germany & BNT162b2 & 72 & 16 & $366.5 \mathrm{AU} / \mathrm{mL}$ & $800 \mathrm{AU} / \mathrm{mL}$ & $\begin{array}{l}\text { Anti-SARS-CoV-2 IgG of } 597,414,140, \\
\text { and } 124 \mathrm{AU} / \mathrm{ml} \text { in MHDs of } 37-59, \\
60-69,70-79, \text { and } 80-90 \text { years, } \\
\text { respectively }\end{array}$ & [37] \\
\hline Germany & $\begin{array}{l}\text { BNT162b2/ } \\
\text { AZD1222 }\end{array}$ & 23 & 14 & 1.6 $\mathrm{AU} / \mathrm{mL}$ & $73.1 \mathrm{AU} / \mathrm{mL}$ & $\begin{array}{l}\text { Significantly higher IgG spike level ( } 818.4 \\
\text { vs. } 73.1 \mathrm{AU} / \mathrm{ml} \text { ) and IgM spike level } \\
\text { (index: } 0.86 \text { vs. } 0.34 \text { ) in MHDs after } \\
\text { COVID-19 infection than those of } \\
\text { controls following single-dose } \\
\text { vaccination }\end{array}$ & [45] \\
\hline Germany & BNT162b2 & 22 & 46 & $6^{\mathrm{b}}$ & $81^{\mathrm{b}}$ & $\begin{array}{l}\text { Anti-S1 IgG index of } 18 \% \text { and } 82 \% \text { in } \\
\text { MHDs following the first and the second } \\
\text { dose, respectively }\end{array}$ & [41] \\
\hline Germany & BNT162b2 & 40 & 35 & $60.3^{c}$ & 99.9 & $\begin{array}{l}\text { RBD-specific B cells identified mostly as } \\
\text { naïve and pre-switch memory B cell in } \\
\text { MHDs, whereas post-switch memory B } \\
\text { cell and plasmablast identified mostly in } \\
\text { controls }\end{array}$ & {$[44]$} \\
\hline Israel & BNT162b2 & 127 & 132 & 116.5 $\mathrm{AU} / \mathrm{Ml}^{\mathrm{d}}$ & $\begin{array}{l}176.5 \\
\mathrm{AU} / \mathrm{mL}\end{array}$ & $\begin{array}{l}\text { Anti-spike } \mathrm{Ab} \text { of } 99.5 \text { and } 122 \mathrm{AU} / \mathrm{ml} \text { in } \\
\text { MHDs less than } 75 \text { and more than } \\
75 \text { years, respectively }\end{array}$ & [38] \\
\hline Israel & BNT162b2 & 56 & 95 & $2900 \mathrm{AU} / \mathrm{mL}$ & $7401 \mathrm{AU} / \mathrm{mL}$ & $\begin{array}{l}\text { Age positively associated with humoral } \\
\text { response (OR, } 1.22) \text {, whereas lymphocyte } \\
\text { count negatively associated with } \\
\text { humoral response }(\mathrm{OR}, 0.83)\end{array}$ & [39] \\
\hline
\end{tabular}

Abbreviations: $\mathrm{Ab}$, antibody; $\mathrm{AE}$, adverse effect; $\mathrm{AU}$, arbitrary unit; $\mathrm{HBV}$, hepatitis $\mathrm{B}$ virus; $\mathrm{MHD}$, maintenance hemodialysis; OR, odds ratio; RBD, receptor-binding domain; RLU, relative light units. ${ }^{a}$ Antibody titer of patients with MHD was detected four weeks after vaccination, whereas that of controls was detected three weeks after vaccination. ${ }^{b}$ The value of the anti-S1 IgG antibody test is expressed as an index: $<1$ was classified as negative, and $\geq 1$ or higher as positive. ${ }^{c}$ Forty MHD and 4 peritoneal dialysis patients were grouped together owing to no difference in age and vaccine response. ${ }^{\mathrm{d}}$ The study included 127 patients with MHD and 33 patients with peritoneal dialysis. The lowest anti-spike antibody level quartile group and the highest anti-spike antibody level quartile group did not differ in dialysis modality. 
However, most previous studies have compared the effectiveness of vaccines according to the humoral response to SARS-CoV-2, and therefore, studies focusing on the cellular immune response following COVID-19 vaccination are warranted. On the other hand, most studies have shown the effectiveness of BNT162b2, although one study reported no significant difference in antibody response compared to AZD1222 [45]. More studies exploring the effectiveness of inactivated whole virus vaccines, viral vector vaccines, other mRNA vaccines, protein subunit vaccines, and mixed prime-boost schedules are also required.

\subsection{Characteristics following Vaccination in Patients with MHD}

The characteristics of patients with MHD following COVID-19 vaccination in the literature are summarized in Table 3. The reported age of these patients ranged from 62 to 76 years, and they were predominantly male (53\% to 95\%). Prior COVID-19 infection was diagnosed within $31 \%$ of the patients, and anti-spike protein IgG antibodies were detected in $34.7 \%$ to $95.4 \%$ following vaccination.

Among the factors associated with a favorable antibody response, previous COVID-19 infection was the most commonly reported. Chan et al. found that an anti-RBD IgG antibody response in MHD patients with prior COVID-19 infection was robust at one week following the first dose of mRNA-1273, whereas a robust response in those without prior COVID-19 infection did not occur until one week following the second dose of vaccine [46]. Billany et al. conducted an experiment of 94 patients with MHD and evaluated antibodies to S1 spike protein against COVID-19 28 days following a single dose of BNT162b2 or AZD1222. Their results showed that previous COVID-19 infection was an indicator of antibody detection [47]. Attias et al. studied the serial responses of anti-spike $1 \mathrm{IgG}$ antibody following BNT162b2 vaccination in 69 patients with MHD. The rate of positive antibody was reported among those with a previous SARS-CoV-2 infection [48]. Younger age has also been associated with antibody response. A study of 101 vaccinated in-center hemodialysis patients by Torreggiani et al. reported that the age of neutralizing SARS-CoV-2 antibody responders was significantly lower than that of non-responders [49]. Frantzen et al. studied 244 in-center hemodialysis patients who received the two-dose BNT162b2 vaccination and observed that the younger patients were more likely to have an antibody response [50]. In addition, serum albumin level was also reported positively associated with antibody response. Agur et al. performed a prospective study of $122 \mathrm{MHD}$ patients evaluating anti-spike SARS-CoV-2 IgG antibodies at an average of 36 days following two doses of BNT162b2. They observed that higher albumin levels, lower intravenous iron doses, and lesser body mass indexes were associated with higher antibody titers in the multivariate analysis [51]. Anand et al. assessed the anti-RBD IgG antibody responses among $610 \mathrm{MHD}$ patients completing vaccination of mRNA-1273, BNT162b2, or Ad26.COV2.S. They found that MHD vintage and serum albumin levels were negatively associated with antibody response [52].

With regards to factors for a poor antibody response other than older age, Longlune et al. found that receiving immunosuppressants was an independent factor for antibody unresponsiveness one month following BNT162b2 vaccination in chronic dialysis patients [53]. Several other studies have also reported similar findings [47,50,54]. Lacson et al. further observed that non-responders after two doses of BNT162b2 or mRNA-1273 were more like to be female, have a shorter dialysis vintage, have received other vaccines, to be hospitalized within 14 days, and have congestive heart failure [54].

Different characters of patients, vaccine type and dosage, definitions of the humoral response, and timepoints of antibody detection may contribute to the variable results across the studies. BNT162b2 was shown to be effective in most previous studies, although the antibody response remained diverse among different vaccines $[47,52,54]$. Current studies have mostly evaluated the effectiveness of vaccines in the form of IgG titers. However, studies involving the cellular responses or human leukocyte antigen are sparse and inconclusive [55-57]. Further studies should be undertaken to enhance the understanding of immune mechanisms following COVID-19 vaccination in patients with MHD. 
Table 3. Characteristics following COVID-19 vaccination in patients with MHD.

\begin{tabular}{|c|c|c|c|c|c|c|c|c|}
\hline Country & Vaccine & MHDs & Age & Male & $\begin{array}{c}\text { Prior } \\
\text { COVID-19 } \\
\text { Infection }\end{array}$ & $\begin{array}{l}\text { Antibody } \\
\text { Positivity }\end{array}$ & $\begin{array}{l}\text { Favorable Factor(s) of } \\
\text { Antibody Response }\end{array}$ & Ref. \\
\hline France & BNT162b2 & 244 & 76 & $70 \%$ & $13 \%$ & $90.6 \%$ & \multirow{5}{*}{$\begin{array}{l}\text { Younger age } \\
\text { Younger age; lower } \\
\text { comorbidity burden } \\
\text { Prior COVID-19 } \\
\text { infection }\end{array}$} & {$[50]$} \\
\hline France & BNT162b2 & 101 & 69 & $59 \%$ & $2 \%$ & $34.7 \%$ & & [49] \\
\hline France & BNT162b2 & 69 & 70 & $78 \%$ & $19 \%$ & $85.9 \%$ & & [48] \\
\hline France & BNT162b2 & 88 & $64^{\mathrm{a}}$ & $69 \%$ a & $6 \%$ & $84.1 \%$ & & [53] \\
\hline France & BNT162b2 & 10 & 71 & $\mathrm{~N} / \mathrm{A}$ & $\mathrm{N} / \mathrm{A}$ & $88.9 \%$ & & [56] \\
\hline Israel & BNT162b2 & 122 & 72 & $66 \%$ & $0 \%$ & $93.4 \%$ & \multirow{3}{*}{$\begin{array}{l}\text { Younger age; higher } \\
\text { albumin level; lower } \\
\text { intravenous iron dose } \\
\text { Higher lymphocytes; } \\
\text { higher hemoglobin } \\
\text { level }\end{array}$} & [51] \\
\hline Spain & $\begin{array}{l}\text { BNT162b2/mRNA- } \\
1273\end{array}$ & 175 & 71 & $67 \%$ & $\mathrm{~N} / \mathrm{A}$ & $95.4 \%$ & & [57] \\
\hline Spain & mRNA-1273 & 78 & 67 & $68 \%$ & $\mathrm{~N} / \mathrm{A}$ & $94.9 \%$ & & {$[58]$} \\
\hline $\begin{array}{l}\text { United } \\
\text { Kingdom }\end{array}$ & BNT162b2/ADZ1222 & 94 & 62 & $60 \%$ & $22 \%$ & $79.8 \%$ & \multirow{3}{*}{$\begin{array}{l}\text { Younger age; prior } \\
\text { COVID-19 infection } \\
\text { Prior COVID-19 } \\
\text { infection } \\
\text { Male; longer dialysis } \\
\text { vintage; prior } \\
\text { COVID-19 infection }\end{array}$} & [47] \\
\hline $\begin{array}{l}\text { United States } \\
\text { of America }\end{array}$ & mRNA-1273 & 61 & 70 & $95 \%$ & $33 \%$ & $95.1 \%$ & & [46] \\
\hline $\begin{array}{l}\text { United States } \\
\text { of America }\end{array}$ & $\begin{array}{c}\text { BNT162b2/mRNA- } \\
1273\end{array}$ & 181 & $68^{b}$ & $53 \% \mathrm{~b}$ & $20 \% b$ & $89 \%$ b & & [54] \\
\hline $\begin{array}{l}\text { United States } \\
\text { of America }\end{array}$ & $\begin{array}{l}\text { BNT162b2/mRNA- } \\
\text { 1273/Ad26.COV2.S }\end{array}$ & 610 & $\mathrm{~N} / \mathrm{A}$ & $\mathrm{N} / \mathrm{A}$ & $15 \%$ & $92.1 \%$ & Higher albumin level & [52] \\
\hline
\end{tabular}

Abbreviations: MHD, maintenance hemodialysis; N/A, not applicable. ${ }^{\text {a }}$ The study included 88 patients with MHD and 24 patients with peritoneal dialysis. ${ }^{\mathrm{b}}$ The study included 181 patients with MHD and 5 patients with peritoneal dialysis.

\section{Conclusions}

The effectiveness of COVID-19 vaccines was observed lesser and more delayed in patients with MHD than in healthy controls among different clinical settings. Less than half of the dialysis patients had positive antibody responses after receiving the first dose of the vaccine. Younger age, previous COVID-19 infection, and higher serum albumin level favored antibody formation, whereas older age and receiving immunosuppressive therapy were negatively associated with antibody formation. Evaluations of the effectiveness of vaccines have mostly focused on specific vaccines, and more studies focusing on different vaccine types, vaccine dosage, heterologous prime-boost schedules, other immune indicators, and risk-benefit analyses of vaccination are urgently needed. In addition, family members and healthcare workers involved with patients on MHD should be vaccinated against SARS-CoV-2, in order that transmission of the virus to those on MHD be minimized.

Author Contributions: Conceptualization, C.-C.Y. and S.-J.H.; writing-original draft preparation, C.-C.Y.; writing-review and editing, S.-Y.L., S.-C.C., Y.-W.C., J.-M.C. and S.-J.H.; supervision, S.-J.H.; All authors have read and agreed to the published version of the manuscript.

Funding: This research received no external funding.

Institutional Review Board Statement: Not applicable.

Informed Consent Statement: Not applicable.

Acknowledgments: Not applicable.

Conflicts of Interest: The authors declare no conflict of interest. 


\section{References}

1. Johnson, K.D.; Harris, C.; Cain, J.K.; Hummer, C.; Goyal, H.; Perisetti, A. Pulmonary and Extra-Pulmonary Clinical Manifestations of COVID-19. Front. Med. 2020, 7, 526. [CrossRef] [PubMed]

2. World Health Organization. WHO COVID-19 Dashboard. Available online: https:/ / covid19.who.int/ (accessed on 4 July 2021).

3. Beigel, J.H.; Tomashek, K.M.; Dodd, L.E.; Mehta, A.K.; Zingman, B.S.; Kalil, A.C.; Hohmann, E.; Chu, H.Y.; Luetkemeyer, A.; Kline, S.; et al. Remdesivir for the Treatment of Covid-19_Final Report. N. Engl. J. Med. 2020, 383, 1813-1826. [CrossRef]

4. RECOVERY Collaborative Group. Dexamethasone in Hospitalized Patients with Covid-19. N. Engl. J. Med. 2020, 384, 693-704. [CrossRef]

5. Bello, A.K.; Levin, A.; Lunney, M.; Osman, M.A.; Ye, F.; Ashuntantang, G.E.; Bellorin-Font, E.; Benghanem Gharbi, M.; Davison, S.N.; Ghnaimat, M.; et al. Status of care for end stage kidney disease in countries and regions worldwide: International cross sectional survey. BMJ 2019, 367, 15873. [CrossRef]

6. United States Renal Data System. 2020 USRDS Annual Data Report: Epidemiology of Kidney Disease in the United States; National Institutes of Health, National Institute of Diabetes and Digestive and Kidney Diseases: Bethesda, MD, USA, 2020.

7. Sharif, M.R.; Chitsazian, Z.; Moosavian, M.; Raygan, F.; Nikoueinejad, H.; Sharif, A.R.; Einollahi, B. Immune disorders in hemodialysis patients. Iran. J. Kidney Dis. 2015, 9, 84-96. [PubMed]

8. Hsu, C.M.; Weiner, D.E.; Aweh, G.; Miskulin, D.C.; Manley, H.J.; Stewart, C.; Ladik, V.; Hosford, J.; Lacson, E.C.; Johnson, D.S.; et al. COVID-19 Among US Dialysis Patients: Risk Factors and Outcomes From a National Dialysis Provider. Am. J. Kidney Dis. 2021, 77, 748-756.e741. [CrossRef]

9. De Meester, J.; De Bacquer, D.; Naesens, M.; Meijers, B.; Couttenye, M.M.; De Vriese, A.S. Incidence, Characteristics, and Outcome of COVID-19 in Adults on Kidney Replacement Therapy: A Regionwide Registry Study. J. Am. Soc. Nephrol. 2021, 32, 385-396. [CrossRef] [PubMed]

10. Clarke, C.; Prendecki, M.; Dhutia, A.; Ali, M.A.; Sajjad, H.; Shivakumar, O.; Lightstone, L.; Kelleher, P.; Pickering, M.C.; Thomas, D.; et al. High Prevalence of Asymptomatic COVID-19 Infection in Hemodialysis Patients Detected Using Serologic Screening. J. Am. Soc. Nephrol. 2020, 31, 1969-1975. [CrossRef] [PubMed]

11. Creput, C.; Fumeron, C.; Toledano, D.; Diaconita, M.; Izzedine, H. COVID-19 in Patients Undergoing Hemodialysis: Prevalence and Asymptomatic Screening During a Period of High Community Prevalence in a Large Paris Center. Kidney Med. 2020, 2, 716-723.e711. [CrossRef]

12. Gilbertson, D.T.; Unruh, M.; McBean, A.M.; Kausz, A.T.; Snyder, J.J.; Collins, A.J. Influenza vaccine delivery and effectiveness in end-stage renal disease. Kidney Int. 2003, 63, 738-743. [CrossRef]

13. Francis, A.; Baigent, C.; Ikizler, T.A.; Cockwell, P.; Jha, V. The urgent need to vaccinate dialysis patients against severe acute respiratory syndrome coronavirus 2: A call to action. Kidney Int. 2021, 99, 791-793. [CrossRef]

14. American Society of Nephrology. Prioritizing COVID-19 Vaccination in Dialysis. Available online: https://www.kidneynews org/view/news/policy-advocacy/leading-edge/prioritizing-covid-19-vaccination-in-dialysis.xml (accessed on 1 June 2021).

15. Combe, C.; Kirsch, A.H.; Alfano, G.; Luyckx, V.A.; Shroff, R.; Kanbay, M.; van der Sande, F.; Basile, C.; EUDIAL Working Group of the ERA-EDTA. At least 156 reasons to prioritize COVID-19 vaccination in patients receiving in-centre haemodialysis. Nephrol. Dial. Transpl. 2021, 36, 571-574. [CrossRef]

16. Garcia, P.; Montez-Rath, M.E.; Moore, H.; Flotte, J.; Fults, C.; Block, M.S.; Han, J.; Dittrich, M.; Parsonnet, J.; Chertow, G.M.; et al. SARS-CoV-2 Vaccine Acceptability in Patients on Hemodialysis: A Nationwide Survey. J. Am. Soc. Nephrol. 2021. [CrossRef] [PubMed]

17. World Health Organization. COVID-19 vaccine tracker and landscape. Available online: https://www.who.int/publications/m/ item/draft-landscape-of-covid-19-candidate-vaccines (accessed on 4 July 2021).

18. Bueno, S.M.; Abarca, K.; González, P.A.; Gálvez, N.M.; Soto, J.A.; Duarte, L.F.; Schultz, B.M.; Pacheco, G.A.; González, L.A.; Vázquez, Y.; et al. Interim report: Safety and immunogenicity of an inactivated vaccine against SARS-CoV-2 in healthy chilean adults in a phase 3 clinical trial. medRxiv 2021. [CrossRef]

19. Al Kaabi, N.; Zhang, Y.; Xia, S.; Yang, Y.; Al Qahtani, M.M.; Abdulrazzaq, N.; Al Nusair, M.; Hassany, M.; Jawad, J.S.; Abdalla, J.; et al. Effect of 2 Inactivated SARS-CoV-2 Vaccines on Symptomatic COVID-19 Infection in Adults: A Randomized Clinical Trial. JAMA 2021. [CrossRef]

20. Logunov, D.Y.; Dolzhikova, I.V.; Shcheblyakov, D.V.; Tukhvatulin, A.I.; Zubkova, O.V.; Dzharullaeva, A.S.; Kovyrshina, A.V.; Lubenets, N.L.; Grousova, D.M.; Erokhova, A.S.; et al. Safety and efficacy of an rAd26 and rAd5 vector-based heterologous prime-boost COVID-19 vaccine: An interim analysis of a randomised controlled phase 3 trial in Russia. Lancet 2021, 397, 671-681. [CrossRef]

21. Sadoff, J.; Gray, G.; Vandebosch, A.; Cárdenas, V.; Shukarev, G.; Grinsztejn, B.; Goepfert, P.A.; Truyers, C.; Fennema, H.; Spiessens, B.; et al. Safety and Efficacy of Single-Dose Ad26.COV2.S Vaccine against Covid-19. N. Engl. J. Med. 2021, 384, 2187-2201. [CrossRef]

22. Polack, F.P.; Thomas, S.J.; Kitchin, N.; Absalon, J.; Gurtman, A.; Lockhart, S.; Perez, J.L.; Pérez Marc, G.; Moreira, E.D.; Zerbini, C.; et al. Safety and Efficacy of the BNT162b2 mRNA Covid-19 Vaccine. N. Engl. J. Med. 2020, 383, 2603-2615. [CrossRef] [PubMed]

23. Baden, L.R.; El Sahly, H.M.; Essink, B.; Kotloff, K.; Frey, S.; Novak, R.; Diemert, D.; Spector, S.A.; Rouphael, N.; Creech, C.B.; et al. Efficacy and Safety of the mRNA-1273 SARS-CoV-2 Vaccine. N. Engl. J. Med. 2020, 384, 403-416. [CrossRef] 
24. Zhang, Y.; Zeng, G.; Pan, H.; Li, C.; Hu, Y.; Chu, K.; Han, W.; Chen, Z.; Tang, R.; Yin, W.; et al. Safety, tolerability, and immunogenicity of an inactivated SARS-CoV-2 vaccine in healthy adults aged 18-59 years: A randomised, double-blind, placebocontrolled, phase 1/2 clinical trial. Lancet Infect. Dis. 2021, 21, 181-192. [CrossRef]

25. Wu, Z.; Hu, Y.; Xu, M.; Chen, Z.; Yang, W.; Jiang, Z.; Li, M.; Jin, H.; Cui, G.; Chen, P.; et al. Safety, tolerability, and immunogenicity of an inactivated SARS-CoV-2 vaccine (CoronaVac) in healthy adults aged 60 years and older: A randomised, double-blind, placebo-controlled, phase $1 / 2$ clinical trial. Lancet Infect. Dis. 2021, 21, 803-812. [CrossRef]

26. Xia, S.; Zhang, Y.; Wang, Y.; Wang, H.; Yang, Y.; Gao, G.F.; Tan, W.; Wu, G.; Xu, M.; Lou, Z.; et al. Safety and immunogenicity of an inactivated SARS-CoV-2 vaccine, BBIBP-CorV: A randomised, double-blind, placebo-controlled, phase 1/2 trial. Lancet Infect. Dis. 2021, 21, 39-51. [CrossRef]

27. Ella, R.; Reddy, S.; Jogdand, H.; Sarangi, V.; Ganneru, B.; Prasad, S.; Das, D.; Raju, D.; Praturi, U.; Sapkal, G.; et al. Safety and immunogenicity of an inactivated SARS-CoV-2 vaccine, BBV152: Interim results from a double-blind, randomised, multicentre, phase 2 trial, and 3-month follow-up of a double-blind, randomised phase 1 trial. Lancet Infect. Dis. 2021. [CrossRef]

28. Voysey, M.; Clemens, S.A.C.; Madhi, S.A.; Weckx, L.Y.; Folegatti, P.M.; Aley, P.K.; Angus, B.; Baillie, V.L.; Barnabas, S.L.; Bhorat, Q.E.; et al. Safety and efficacy of the ChAdOx1 nCoV-19 vaccine (AZD1222) against SARS-CoV-2: An interim analysis of four randomised controlled trials in Brazil, South Africa, and the UK. Lancet 2021, 397, 99-111. [CrossRef]

29. Logunov, D.Y.; Dolzhikova, I.V.; Zubkova, O.V.; Tukhvatulin, A.I.; Shcheblyakov, D.V.; Dzharullaeva, A.S.; Grousova, D.M.; Erokhova, A.S.; Kovyrshina, A.V.; Botikov, A.G.; et al. Safety and immunogenicity of an rAd26 and rAd5 vector-based heterologous prime-boost COVID-19 vaccine in two formulations: Two open, non-randomised phase $1 / 2$ studies from Russia. Lancet 2020, 396, 887-897. [CrossRef]

30. Sadoff, J.; Le Gars, M.; Shukarev, G.; Heerwegh, D.; Truyers, C.; de Groot, A.M.; Stoop, J.; Tete, S.; Van Damme, W.; Leroux-Roels, I.; et al. Interim Results of a Phase 1-2a Trial of Ad26.COV2.S Covid-19 Vaccine. N. Engl. J. Med. 2021, 384, 1824-1835. [CrossRef] [PubMed]

31. Zhu, F.C.; Guan, X.H.; Li, Y.H.; Huang, J.Y.; Jiang, T.; Hou, L.H.; Li, J.X.; Yang, B.F.; Wang, L.; Wang, W.J.; et al. Immunogenicity and safety of a recombinant adenovirus type-5-vectored COVID-19 vaccine in healthy adults aged 18 years or older: A randomised, double-blind, placebo-controlled, phase 2 trial. Lancet 2020, 396, 479-488. [CrossRef]

32. Kallen, K.J.; Theß, A. A development that may evolve into a revolution in medicine: mRNA as the basis for novel, nucleotide-based vaccines and drugs. Ther. Adv. Vaccines 2014, 2, 10-31. [CrossRef] [PubMed]

33. Chu, L.; McPhee, R.; Huang, W.; Bennett, H.; Pajon, R.; Nestorova, B.; Leav, B. A preliminary report of a randomized controlled phase 2 trial of the safety and immunogenicity of mRNA-1273 SARS-CoV-2 vaccine. Vaccine 2021, 39, 2791-2799. [CrossRef] [PubMed]

34. Liljeqvist, S.; Ståhl, S. Production of recombinant subunit vaccines: Protein immunogens, live delivery systems and nucleic acid vaccines. J. Biotechnol. 1999, 73, 1-33. [CrossRef]

35. Yang, S.; Li, Y.; Dai, L.; Wang, J.; He, P.; Li, C.; Fang, X.; Wang, C.; Zhao, X.; Huang, E.; et al. Safety and immunogenicity of a recombinant tandem-repeat dimeric RBD-based protein subunit vaccine (ZF2001) against COVID-19 in adults: Two randomised, double-blind, placebo-controlled, phase 1 and 2 trials. Lancet Infect. Dis. 2021. [CrossRef]

36. Ryzhikov, A.B.; Ryzhikov, E.A.; Bogryantseva, M.P.; Usova, S.V.; Danilenko, E.D.; Nechaeva, E.A.; Pyankov, O.V.; Pyankova, O.G.; Gudymo, A.S.; Bodnev, S.A.; et al. A single blind, placebo-controlled randomized study of the safety, reactogenicity and immunogenicity of the "EpiVacCorona" Vaccine for the prevention of COVID-19, in volunteers aged 18-60 years (phase I-II). Russ. J. Infect. Immun. 2021, 11, 283-296. [CrossRef]

37. Jahn, M.; Korth, J.; Dorsch, O.; Anastasiou, O.E.; Sorge-Hädicke, B.; Tyczynski, B.; Gäckler, A.; Witzke, O.; Dittmer, U.; Dolff, S.; et al. Humoral Response to SARS-CoV-2-Vaccination with BNT162b2 (Pfizer-BioNTech) in Patients on Hemodialysis. Vaccines 2021, 9, 360. [CrossRef]

38. Yanay, N.B.; Freiman, S.; Shapira, M.; Wishahi, S.; Hamze, M.; Elhaj, M.; Zaher, M.; Armaly, Z. Experience with SARS-CoV-2 BNT162b2 mRNA vaccine in dialysis patients. Kidney Int. 2021, 99, 1496-1498. [CrossRef]

39. Grupper, A.; Sharon, N.; Finn, T.; Cohen, R.; Israel, M.; Agbaria, A.; Rechavi, Y.; Schwartz, I.F.; Schwartz, D.; Lellouch, Y.; et al. Humoral Response to the Pfizer BNT162b2 Vaccine in Patients Undergoing Maintenance Hemodialysis. Clin. J. Am. Soc. Nephrol. 2021. [CrossRef]

40. Goupil, R.; Benlarbi, M.; Beaubien-Souligny, W.; Nadeau-Fredette, A.C.; Chatterjee, D.; Goyette, G.; Gunaratnam, L.; Lamarche, C.; Tom, A.; Finzi, A.; et al. Short-term antibody response after 1 dose of BNT162b2 vaccine in patients receiving hemodialysis. CMAJ 2021, 193, E793-E800. [CrossRef]

41. Speer, C.; Göth, D.; Benning, L.; Buylaert, M.; Schaier, M.; Grenz, J.; Nusshag, C.; Kälble, F.; Kreysing, M.; Reichel, P.; et al. Early Humoral Responses of Hemodialysis Patients after COVID-19 Vaccination with BNT162b2. Clin. J. Am. Soc. Nephrol. 2021. [CrossRef]

42. Simon, B.; Rubey, H.; Treipl, A.; Gromann, M.; Hemedi, B.; Zehetmayer, S.; Kirsch, B. Haemodialysis patients show a highly diminished antibody response after COVID-19 mRNA vaccination compared to healthy controls. Nephrol. Dial. Transpl. 2021. [CrossRef]

43. Danthu, C.; Hantz, S.; Dahlem, A.; Duval, M.; Ba, B.; Guibbert, M.; El Ouafi, Z.; Ponsard, S.; Berrahal, I.; Achard, J.M.; et al. Humoral Response after SARS-Cov-2 mRNA Vaccine in a Cohort of Hemodialysis Patients and Kidney Transplant Recipients. J. Am. Soc. Nephrol. 2021. [CrossRef] 
44. Rincon-Arevalo, H.; Choi, M.; Stefanski, A.L.; Halleck, F.; Weber, U.; Szelinski, F.; Jahrsdörfer, B.; Schrezenmeier, H.; Ludwig, C.; Sattler, A.; et al. Impaired humoral immunity to SARS-CoV-2 BNT162b2 vaccine in kidney transplant recipients and dialysis patients. Sci Immunol. 2021. [CrossRef] [PubMed]

45. Lesny, P.; Anderson, M.; Cloherty, G.; Stec, M.; Haase-Fielitz, A.; Haarhaus, M.; Santos, C.; Lucas, C.; Macario, F.; Haase, M. Immunogenicity of a first dose of mRNA- or vector-based SARS-CoV-2 vaccination in dialysis patients: A multicenter prospective observational pilot study. J. Nephrol. 2021. [CrossRef] [PubMed]

46. Chan, L.; Fuca, N.; Zeldis, E.; Campbell, K.; Shaikh, A. Antibody Response to mRNA-1273 SARS-CoV-2 Vaccine in Hemodialysis Patients with and without Prior COVID-19. Clin. J. Am. Soc. Nephrol. 2021. [CrossRef]

47. Billany, R.E.; Selvaskandan, H.; Adenwalla, S.F.; Hull, K.L.; March, D.S.; Burton, J.O.; Bishop, N.C.; Carr, E.J.; Beale, R.; Tang, J.W.; et al. Seroprevalence of antibody to S1 spike protein following vaccination against COVID-19 in patients receiving hemodialysis: A call to arms. Kidney Int. 2021, 99, 1492-1494. [CrossRef]

48. Attias, P.; Sakhi, H.; Rieu, P.; Soorkia, A.; Assayag, D.; Bouhroum, S.; Nizard, P.; El Karoui, K. Antibody response to the BNT162b2 vaccine in maintenance hemodialysis patients. Kidney Int. 2021, 99, 1490-1492. [CrossRef]

49. Torreggiani, M.; Blanchi, S.; Fois, A.; Fessi, H.; Piccoli, G.B. Neutralizing SARS-CoV-2 antibody response in dialysis patients after the first dose of the BNT162b2 mRNA COVID-19 vaccine: The war is far from being won. Kidney Int. 2021, 99, $1494-1496$. [CrossRef]

50. Frantzen, L.; Cavaille, G.; Thibeaut, S.; El-Haik, Y. Efficacy of the BNT162b2 mRNA Covid-19 Vaccine in a hemodialysis cohort. Nephrol. Dial. Transpl. 2021. [CrossRef] [PubMed]

51. Agur, T.; Ben-Dor, N.; Goldman, S.; Lichtenberg, S.; Herman-Edelstein, M.; Yahav, D.; Rozen-Zvi, B.; Zingerman, B. Antibody response to mRNA SARS-CoV-2 vaccine among dialysis patients-A prospective cohort study. Nephrol. Dial. Transpl. 2021. [CrossRef]

52. Anand, S.; Montez-Rath, M.; Han, J.; Garcia, P.; Cadden, L.; Hunsader, P.; Kerschmann, R.; Beyer, P.; Dittrich, M.; Block, G.; et al. Antibody Response to COVID-19 Vaccination in Patients Receiving Dialysis. J. Am. Soc. Nephrol. 2021. [CrossRef] [PubMed]

53. Longlune, N.; Nogier, M.B.; Miedougé, M.; Gabilan, C.; Cartou, C.; Seigneuric, B.; Del Bello, A.; Marion, O.; Faguer, S.; Izopet, J.; et al. High immunogenicity of a messenger RNA based vaccine against SARS-CoV-2 in chronic dialysis patients. Nephrol. Dial. Transpl. 2021. [CrossRef]

54. Lacson, E.; Argyropoulos, C.P.; Manley, H.J.; Aweh, G.; Chin, A.I.; Salman, L.H.; Hsu, C.M.; Johnson, D.S.; Weiner, D.E. Immunogenicity of SARS-CoV-2 Vaccine in Dialysis. medRxiv 2021. [CrossRef]

55. Kho, M.M.L.; Reinders, M.E.J.; Baan, C.C.; van Baarle, D.; Bemelman, F.J.; Diavatopoulos, D.A.; Gansevoort, R.T.; van der Klis, F.R.M.; Koopmans, M.P.G.; Messchendorp, A.L.; et al. The RECOVAC IR study: The immune response and safety of the mRNA-1273 COVID-19 vaccine in patients with chronic kidney disease, on dialysis, or living with a kidney transplant-A prospective, controlled, multicenter observational cohort by the REnal patients COVID-19 VACcination (RECOVAC) consortium COVID-19 VACcination (RECOVAC) consortium. Nephrol. Dial. Transpl. 2021. [CrossRef]

56. Bertrand, D.; Hamzaoui, M.; Lemée, V.; Lamulle, J.; Hanoy, M.; Laurent, C.; Lebourg, L.; Etienne, I.; Lemoine, M.; Le Roy, F.; et al. Antibody and T Cell Response to SARS-CoV-2 Messenger RNA BNT162b2 Vaccine in Kidney Transplant Recipients and Hemodialysis Patients. J. Am. Soc. Nephrol. 2021. [CrossRef] [PubMed]

57. Broseta, J.J.; Rodríguez-Espinosa, D.; Rodríguez, N.; Mosquera, M.D.M.; Marcos, M.; Egri, N.; Pascal, M.; Soruco, E.; Bedini, J.L.; Bayés, B.; et al. Humoral and Cellular Responses to mRNA-1273 and BNT162b2 SARS-CoV-2 Vaccines Administered to Hemodialysis Patients. Am. J. Kidney Dis. 2021. [CrossRef] [PubMed]

58. Monzó, J.J.B.; Rodríguez-Espinosa, D.; Soruco, E.; Maduell, F. Weekly seroconversion rate of the mRNA-1273 SARS-CoV-2 vaccine in hemodialysis patients. Nephrol. Dial. Transpl. 2021. [CrossRef] 